DOI: 10.22616/j.balticsurveying.2018.021

\title{
ACCURACY ESTIMATION ANALYSIS OF LAND PARCEL AREA DETERMINATION BASED ON AEROSURVEYING MATERIALS IN COMPARISON WITH RESULTS OF GROUND GEODETIC MEASUREMENTS
}

\author{
Anatoliy Tserklevich ${ }^{1}$, Vasyl Khoptar ${ }^{1}$ \\ ${ }^{1}$ Lviv Polytechnic National University, Lviv, Ukraine
}

\begin{abstract}
The presence of a large number of territorial units with a high price of land determines the appropriate accuracy of their area determination in the short term. The widespread use of unmanned aerial vehicles (UAVs) is a modern geospatial mapping technology. Using an UAV equipped with appropriate devices for aerosurveying such as, for example, the Trimble UX5 - is economically feasible in comparison with ground geodetic measurements, since the latter requires a lot of costs. Therefore, the main purpose of this study is to analyze accuracy estimation of land parcel area determination based on aero surveying materials using an unmanned aerial vehicle (UAV) in comparison with results of ground geodetic measurements using a total station. As a result, a comparison of detailed plan and an existing base of land parcel measurements with accuracy estimations have been made. Based on our analysis and experimental studies, we can state that the UAV allows more efficient data collection within the requirements of land management in comparison with ground geodetic measurements. The use of aero surveying materials for determination of land parcel areas has been proposed. The results of the study provide an opportunity to improve the reliability of land parcel data in the normative and methodological framework.

Key words: accuracy; area; land parcel; unmanned aerial vehicle; orthophotomaps.
\end{abstract}

\section{Introduction}

Innovation development in geodesy focused largely on obtaining a more voluminous set of data with high accuracy. It is especially acute problem of creating an actual normative-methodical base for land inventory both within and outside settlements. Therefore, it is very important to carry out continuous monitoring of land use and making changes to data for formation of cadastral situation of territories [Opalinskiy, 2010].

Geodetic works remain the main means of obtaining relevant and reliable information for land management and cadastre. The use of unmanned aerial vehicles (UAVs) for geodetic measurements is currently widespread and they are used for many tasks, including land-use projects. Heretofore, it is unclear whether it is possible to apply UAVs for individual land parcel and land inventory.

Appropriate issue in the geodetic works is the timing of their implementation. There is a lot of equipment on the market, such as total stations, GPS receivers, laser scanners, as well as software for processing of received data. All this simplifies and accelerates production of geodetic works, but sometimes this is not enough.

Aerosurveying - photographing process of terrestrial surface from an aircraft - one of technologies that allows, partially, to solve the problems described above. The use of data obtained from UAVs surveying - orthophotomaps - shortens timing, increases productivity of works and allows, in many cases, to refuse to carry out the surveying by ground method [Petrie, 2013].

The main information obtained from surveying works for ensuring of inventory is area of land parcel. Therefore, improving methods and instruments of land inventory is an actual topic of scientific research.

Land inventory is a set of works, for example [Inventaryzatsiya zemel ..., 1993; Polozhennya pro zemelnokadastrovu inventaryzatsiyu ..., 1997], which includes collection and analysis of bulk archive documentation on land management, a large number of legal documents; creation and decipherment of orthophotomaps; performing field geodetic works, etc. The paper [Opalinskiy, 2010] describes in detail the methodology of data work, in which the author claims that the technology of land inventory implies that all materials are firstly integrated into geographic information systems (GIS). In GIS- 
environments, land parcel area calculations are also performed, summary tabular and graphic materials are formed. The author of this work is convinced that a significant economic effect can be achieved precisely with the use of UAVs.

For example, in works [Tserklevych, 1999; Tserklevich, Protsik, 1997; Tserklevich, Siglyak, 1999] the technology of conducting geodetic measurements in the inventory of settlements is proposed. As stated in [Tserklevich A., Kalinich I., 2015], the question about substantiation of necessary accuracy of land parcel area determination during cadastral surveying becomes very important in recent times. Accordingly, a large number of native and foreign scientists engaged in study of accuracy of land parcel area determination.

The paper [Tserklevych, 1999] analyzes accuracy of determining land parcel boundaries and land parcel areas for purpose of land inventorying of settlements. The obtained results of these studies confirmed the necessity of adding a marginal error of land parcel areas into the instructional materials, within which the area could be compared with their repeated measurements.

In paper [Tserklevich A., Chernyagha P., 2002] a method is proposed for assessing the accuracy of land parcel area determination by contours of theodolite measurements. Based on analysis of this study, the authors asserted that, depending on a value of mean square error of the coordinates of turning points of land parcel boundaries proportional to change in the mean square error of its area.

Based on [Tserklevich, Siglyak, 1999], we can conclude that the values of mean square error of land parcel areas $m_{p}$ and relative errors $\frac{m_{p}}{P}$ in a certain approximation are consistent regardless of method of their calculation.

Another important aspect of impact on the accuracy of land parcel areas is economic factor. This problem is discussed in details in [Volosetskyy, 1999], as a result of which the value of error in land parcel area determination was obtained by the method of monetary valuation.

The state of this problem was considered in details in paper [Shendyapina, 2004], where the formulas for calculating the accuracy of land parcel areas determination were analyzed, and it was found that the use of aerosurveying materials can provide land parcel area determination not only in rural settlements, but also in small towns and settlements.

The aim of this work is to investigate the possibility of land parcel area determination based on aerosurveying materials, as well as the analysis of accuracy of data obtained using UAVs compared with the results of surveying by ground method.

\section{Methodology of research and materials}

Ground-based methods of cadastral surveying are currently the most commonly used methods to obtain high-precision terrain information. Using GNSS station networks in real time kinematic (RTK), or tacheometry method, surveyor can perform hundreds of points per day.

On the other hand, surveying using of UAVs allows operatively, at low cost level, to carry out aerosurveying of lands in order to build an orthophotomaps for various engineering and economic tasks. Aerosurveying consists of two main stages: image getting and processing.

Aerial images are taken using an UAV that is equipped with a high-resolution digital camera installed on UAV board. An example of such technology may be Trimble UX5 UAV with the following characteristics [Vovk, Hlotov, Hunina, Malitskyy, Tretyak, Tserklevych, 2015]:

- Range of flight heights: 75-750 m, cruising height: $150 \mathrm{~m}$.

- Cruising speed: $80 \mathrm{~km} / \mathrm{h}$.

- Maximum flight time: 50 min.

- Remote control range: up to $5 \mathrm{~km}$.

- Image quality (pixel size): up to $5 \mathrm{~cm}$.

- Accuracy of surface modeling in plan: $\pm 5 \mathrm{~cm}$, in height: $\pm 10 \mathrm{~cm}$.

- Calibrated digital camera: SONY NEX 5R.

This UAV is designed to produce high-quality orthophotomaps and digital terrain model.

The flight is performed completely in automatic mode - from take-off to landing. The ground control station is used for launch, flight control and surveying. At the stage of image processing using special 
software, aerosurveying material - orthophotomaps are produced. In determining land parcel areas based on orthophotomaps a geometric method is used, which consists of measuring linear elements of the land parcel. The smaller is a land parcel, the greater is a relative error of determining its area [Shendyapina, 2004].

In order to determine land parcel areas, we used the materials of aerosurveying on the territory of Grabovets village, Stryi district, Lviv region. With the help of software Digitals [http://www.vinmap.net/], on the base of received orthophotomaps, we collected the contours of land parcels (only sections with clearly defined contours were taken into account), as shown in Figure 1. From our experience, the boundaries of land parcels are not properly secured. Often, it is an obsolete fence or hedge, where it is difficult to determine unambiguously the geometric center of turning angle. When comparing the data obtained on orthophotomaps and results of land-based extraction using a total station, differences in contours of land parcels is observed, which characterizes accuracy of works.

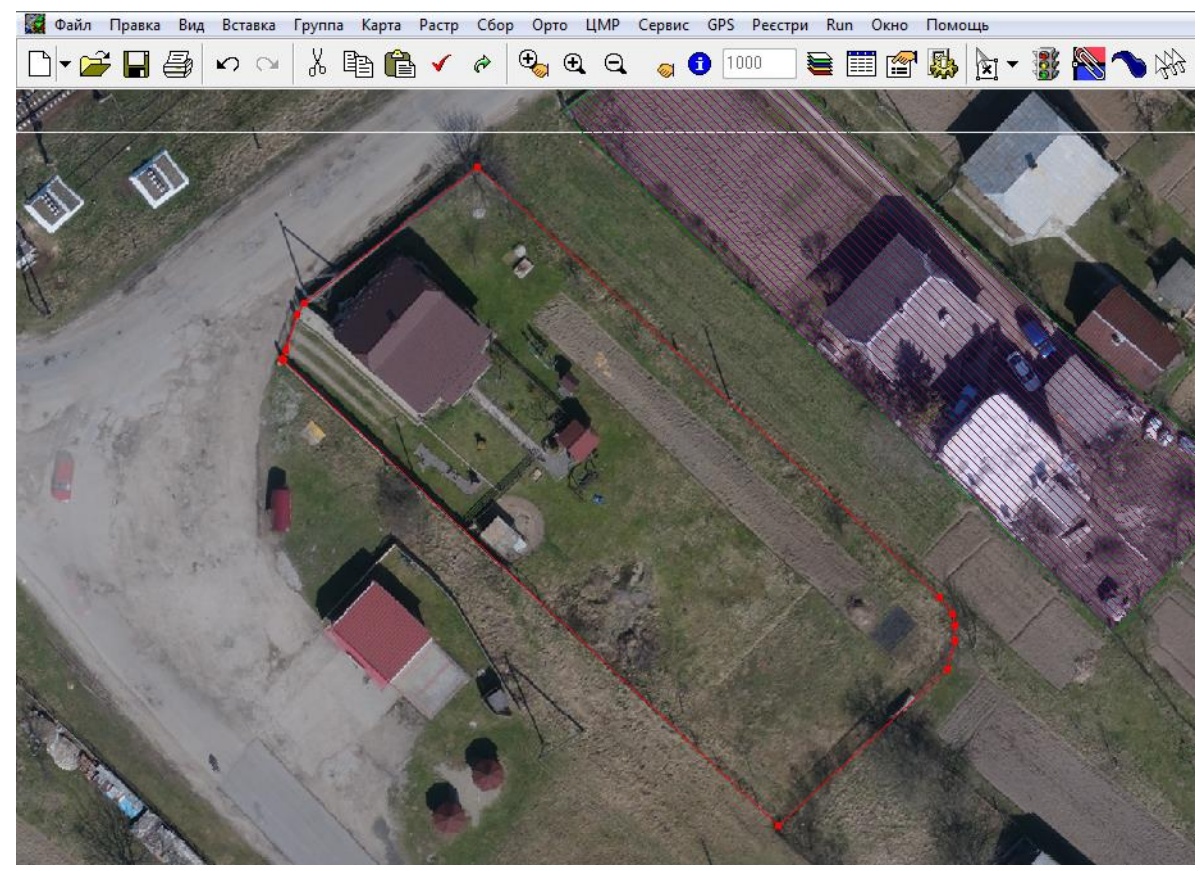

Fig. 1. Land parcel contour on the orthophotomap

According to normative and technical documents [Opalinskiy, 2010; Tserklevych, 1999] the permissible relative error of area determination should not exceed the value of $1: 1000$ (which is $0.1 \%$ of land parcel price), and error of position in plane of measurement base points and boundary marks is $0.10 \mathrm{~m}$. Accuracy calculation of land parcel areas determination is obtained by following formula:

$$
m_{p}=m_{t} \sqrt{P}
$$

where $m_{t}-$ average square error of boundary mark position; $P-$ land parcel area.

During measurements in order to determine land parcel area, their accuracy depends on accuracy of linear and angular measurements, so double calculations of area by different measurements due to their errors leads to two values of area [Tserklevich, Siglyak, 1999]. Therefore, it is reasonable to assume that difference between these two values of area cannot exceed the margin of error. Marginal error $(\Delta p)$ of land parcel area is determined by the following formula:

$$
\Delta p=2,5 \cdot m_{p}
$$


And the permissible difference ( $\Delta p_{\text {diff }}$ ) of land parcel area obtained by different methods, - by the formula:

$$
\Delta p_{\text {diff }}=\Delta p \cdot \sqrt{2}
$$

As an example, by the formulas (1-3), in Table 1 calculations of above estimates for land of small towns and villages are performed. The average square error of boundary mark $m_{t}=0,10 \mathrm{~m}$ is fixed for this gradation of land.

Estimation for land parcels of small towns and villages

\begin{tabular}{|c|c|c|c|c|c|}
\hline $\begin{array}{c}\text { Gradation } \\
\text { of land }\end{array}$ & $\begin{array}{c}\text { Average } \\
\text { square } \\
\text { error of } \\
\text { boundary } \\
\text { mark } \\
\text { position, } \\
m_{t}, \mathbf{m}\end{array}$ & $\begin{array}{c}\text { Land } \\
\text { parcel } \\
\text { area, }\end{array}$ & $\begin{array}{c}\text { Average square } \\
\text { error of area, } \\
m_{p}=m_{t} \sqrt{P} \\
\text { ha }\end{array}$ & $\begin{array}{c}\text { Marginal error of } \\
\text { area, } \\
\Delta p=2,5 \cdot m_{p},\end{array}$ & $\begin{array}{c}\text { Permissible difference } \\
\text { of area, } \\
\text { ha }\end{array}$ \\
\hline $\begin{array}{c}\text { Land of } \\
\text { towns and } \\
\text { villages }\end{array}$ & 0,10 & 0,010 & 0,0001 & & $\Delta p \cdot \sqrt{2}$ \\
diff & & 0,0003 & 0,00025 & ha \\
\hline
\end{tabular}

In reality, there are also other sizes of land parcels, with corresponding errors of boundary marks position and measurements of sides.

\section{Discussions and results}

Based on gotten aerosurveying materials and data set of results of ground methods surveying on the territory of Hrabovets village, the accuracy of determination of land parcel areas was evaluated. Below, in Table 2, the data obtained as results of studies are given, and on picture 2 the differences and marginal errors between the land parcel areas are shown, that is taken from aerosurveying and by ground-based surveying using a total station.

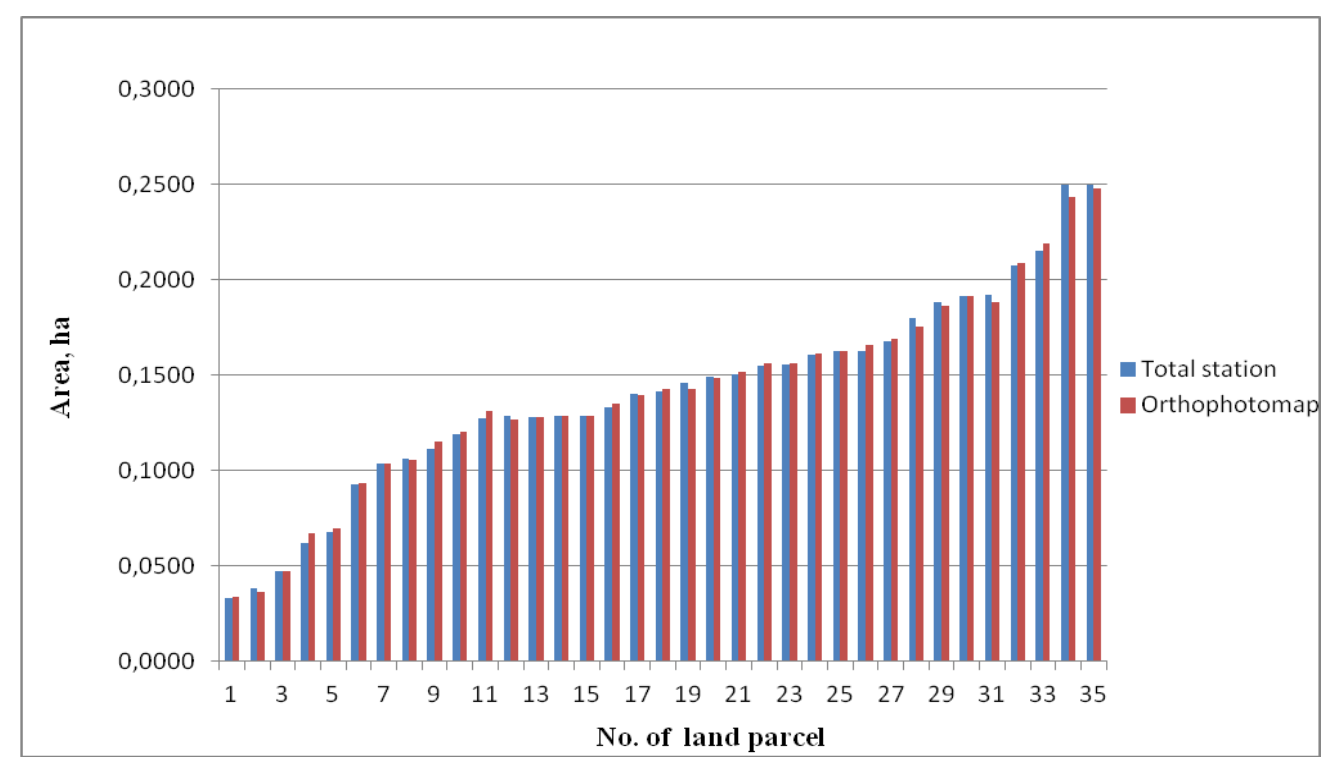

Fig. 2. Diagram of differences between areas determination by aerosurveying and based on ground method 
Table 2

Differences in land parcel areas determination

\begin{tabular}{|c|c|c|c|c|c|}
\hline No. & Cadastral number & $\begin{array}{c}\text { Land parcel area } \\
\text { (ground method), } \\
\text { ha }\end{array}$ & $\begin{array}{c}\text { Land parcel area } \\
\text { (aerosurveying), } \\
\text { ha }\end{array}$ & $\begin{array}{c}\text { Difference, } \\
\mathbf{m}^{2}\end{array}$ & $\begin{array}{l}\text { Marginal } \\
\text { error, } \mathbf{m}^{2}\end{array}$ \\
\hline 1 & 2 & 3 & 4 & 5 & 6 \\
\hline 1 & 4625380600:01:004:0019 & 0,0335 & 0,0337 & 2 & 1,84 \\
\hline 2 & 4625380600:01:005:0149 & 0,0384 & 0,0366 & 18 & 1,91 \\
\hline 3 & 4625380600:01:004:0018 & 0,0476 & 0,0472 & 4 & 2,17 \\
\hline 4 & 4625380600:01:012:0167 & 0,0620 & 0,0671 & 51 & 2,59 \\
\hline 5 & 4625380600:01:005:0024 & 0,0682 & 0,0696 & 14 & 2,64 \\
\hline 6 & 4625380600:01:005:0027 & 0,0932 & 0,0933 & 1 & 3,05 \\
\hline 7 & 4625380600:01:012:0099 & 0,1039 & 0,1036 & 3 & 3,22 \\
\hline 8 & 4625380600:01:012:0158 & 0,1061 & 0,1056 & 5 & 3,25 \\
\hline 9 & 4625380600:01:012:0013 & 0,1115 & 0,1152 & 37 & 3,39 \\
\hline 10 & 4625380600:01:012:0181 & 0,1190 & 0,1204 & 14 & 3,47 \\
\hline 11 & 4625380600:01:012:0007 & 0,1276 & 0,1311 & 35 & 3,62 \\
\hline 12 & 4625380600:01:005:0026 & 0,1288 & 0,1270 & 18 & 3,56 \\
\hline 13 & 4625380600:01:012:0005 & 0,1283 & 0,1284 & 1 & 3,58 \\
\hline 14 & 4625380600:01:012:0182 & 0,1285 & 0,1286 & 1 & 3,59 \\
\hline 15 & 4625380600:01:012:0182 & 0,1285 & 0,1286 & 1 & 3,59 \\
\hline 16 & 4625380600:01:012:0018 & 0,1335 & 0,1351 & 16 & 3,68 \\
\hline 17 & 4625380600:01:012:0149 & 0,1403 & 0,1396 & 7 & 3,74 \\
\hline 18 & 4625380600:01:012:0134 & 0,1414 & 0,1429 & 15 & 3,78 \\
\hline 19 & 4625380600:01:012:0078 & 0,1463 & 0,1431 & 32 & 3,78 \\
\hline 20 & 4625380600:01:012:0064 & 0,1491 & 0,1485 & 6 & 3,85 \\
\hline 21 & 4625380600:01:013:0002 & 0,1503 & 0,1519 & 16 & 3,90 \\
\hline 22 & 4625380600:01:012:0055 & 0,1550 & 0,1565 & 15 & 3,96 \\
\hline 23 & 4625380600:01:012:0121 & 0,1560 & 0,1561 & 1 & 3,95 \\
\hline 24 & 4625380600:01:005:0025 & 0,1610 & 0,1614 & 4 & 4,02 \\
\hline 25 & 4625380600:01:012:0097 & 0,1628 & 0,1628 & 0 & 4,03 \\
\hline 26 & 4625380600:01:012:0103 & 0,1628 & 0,1661 & 33 & 4,08 \\
\hline 27 & 4625380600:01:012:0054 & 0,1680 & 0,1695 & 15 & 4,12 \\
\hline 28 & 4625380600:01:012:0069 & 0,1798 & 0,1757 & 41 & 4,19 \\
\hline 29 & 4625380600:01:003:0006 & 0,1883 & 0,1863 & 20 & 4,32 \\
\hline 30 & 4625380600:01:012:0156 & 0,1918 & 0,1918 & 0 & 4,38 \\
\hline 31 & 4625380600:01:012:0073 & 0,1921 & 0,1886 & 35 & 4,34 \\
\hline 32 & 4625380600:01:013:0007 & 0,2078 & 0,2089 & 11 & 4,57 \\
\hline 33 & 4625380600:01:004:0003 & 0,2154 & 0,2192 & 38 & 4,68 \\
\hline 34 & 4625380600:01:013:0004 & 0,2500 & 0,2434 & 66 & 4,93 \\
\hline 35 & 4625380600:01:012:0022 & 0,2500 & 0,2478 & 22 & 4,98 \\
\hline
\end{tabular}

Analyzing values of difference between areas and marginal errors of land parcels in Table 2, we can see that all measurements are at the required level of accuracy, which allows us to assert that aerosurveying with the help of UAV can be used to determine the land parcel areas to ensure the requirements of land inventory. 


\section{Conclusions and proposals}

In this article, it was proposed to use surveying results from UAV to determine land parcel areas. Unlike ground-based geodetic methods, using UAV allows quickly and cost-effectively perform aerosurveying of territories.

The conducted theoretical research and practical recommendations make it possible to improve the reliability of the data on accuracy of the land parcel area determination based on aerosurveying materials compared to results of measurement by ground method, which will promote the development of territories and improve the investment climate.

When comparing the results of this study, we can say that obtained values of the land parcel areas on the territory of Grabovets village are within the required precision. In many cases, the results of our research give grounds to assert that high-resolution orthophotomaps can be used for land parcel areas determination, as well as for land inventory of settlement.

\section{References}

1. Vovk A., Hlotov V., Hunina A., Malitskyy A., Tretyak K., Tserklevych A. (2015) Analiz rezultativ dlya stvorennya ortofotoplaniv ta tsyfrovykh modeley relyefu iz zastosuvannyam BPLA TRIMBLE UX-5. Heodeziya, kartohrafiya i aerofotoznimannya: mizhvidomchyy naukovo-tekhnichnyy zbirnyk. Vypusk 81. Lviv, s. 90-103 (in Ukrainian).

2. Volosetskyy B. (1999) Analiz tochnosti vyznachennya parametriv zemelnykh dilyanok $\mathrm{v}$ naselenykh punktakh z vrakhuvannyam ekonomichnykh chynnykiv. Suchasni dosyahnennya heodezychnoyi nauky ta vyrobnytstva. Lviv. s. 119-121 (in Ukrainian).

3. Inventaryzatsiya zemel naselenykh punktiv (nazemni metody) (1993) Kerivnyy tekhnichnyy material. 15 s. (in Ukrainian).

4. Opalinskiy A. (2010) Inventarizatsiya zemel' v naselennykh punktakh i za ikh predelami. Elektronnyy nauchno-tekhnicheskiy zhurnal «Geoprofil». No. 1, s. 9-16, (in Russian).

5. The official site of Digitals. Viewed 28 February, 2018, (http://www.vinmap.net/).

6. Polozhennya pro zemelno-kadastrovu inventaryzatsiyu zemel naselenykh punktiv (1997) Zakonodavstvo Ukrayiny, No. 522/2326, 12 s., (in Ukrainian).

7. Tserklevych A. (1999) Vykorystannya novykh tekhnolohiy i aktualni zadachi zemelnoho kadastru. Suchasni dosyahnennya heodezychnoyi nauky ta vyrobnytstva. Lviv, s. 121-124 (in Ukrainian).

8. Tserklevich A., Protsik M. (1997) Pro tochnist vyznachennya polozhen hranychnykh znakiv i rozrakhunku ploshchi zemli. Suchasni dosyahnennya heodezychnoyi nauky ta vyrobnytstva. Lviv. s. 185-188 (in Ukrainian).

9. Tserklevich A., Siglyak M. (1999) Pro tochnist vyznachennya mezh ta ploshch zemelnykh dilyanok pry vykonanni inventaryzatsiyi zemel naselenykh punktiv. Suchasni dosyahnennya heodezychnoyi nauky ta vyrobnytstva. Lviv. s. 124-130 (in Ukrainian).

10. Tserklevich A., Chernyagha P. (2002) Koordynuvannya mezh zemelnykh dilyanok i tochnist vyznachennya yikhnikh ploshch. Zemlevporyadnyy visnyk. - No. 2., p. 24-28 (in Ukrainian).

11. Tserklevich A., Kalinich I. (2015) Yakist heoprostorovykh danykh natsionalnoyi kadastrovoyi cystemy i problemni pytannya vstanovlennya (vidnovlennya) vezh zemelnykh dilyanok. Visnyk heodeziyi ta kartohrafiyi. No. 3., s. 32-40 (in Ukrainian).

12. Shendyapina S. (2004) Sovershenstvovaniye tekhnologii mezhevaniya zemel na baze primeneniya elektronnoy izmeritelnoy tekhniki i materialov aerofotosyemki: dis. kand. tekhn. nauk. Moskva, 92 s., (in Russian).

13. Petrie, G. (2013) Commercial operation of lightweight UAVs for aerial imaging and mapping. GEOInformatics, vol. 16, No. 1, p. 28-39.

Information about authors

Anatoliy Tserklevich, Doctor of Science, Professor, Dean of Engineering Geodesy Department, Institute of Geodesy, Lviv Polytechnic National University, S. Bandera str., 12, Lviv, Ukraine, 79013

Vasyl Khoptar, Master of Science, Ph.D.-student, Department of Engineering Geodesy, Institute of Geodesy, Lviv Polytechnic National University, S. Bandera str., 12, Lviv, Ukraine, 79013, e-mail: vasyl.khoptar@gmail.com 